\title{
PELAKSANAAN PENDIDIKAN AGAMA PADASEKOLAH NEGERI PAREPARE
}

\author{
The Implementation of Religious Education \\ At the Extraordinary School in Parepare
}

\author{
Asnandar Abubakar \\ Balai Litbang Agama Makassar \\ Jl. AP. Pettarani No. 72 Makassar 90222 \\ Email: dalo_92@yahoo.com
}

Naskah diterima tanggal 27 Juli 2013. Naskah direvisi tanggal 2 Agustus 2013. Naskah disetujui tanggal 29 Agustus 2013

\begin{abstract}
Abstrak
Penelitian ini dilaksanakan untuk mengetahui bagaimana pelaksanaan pendidikan agama di Sekolah Luar Biasa Negeri Pareare pada jenjang sekolah dasar dengan jenis layanan tuna Rungu dan tuna grahita. Pada pelaksanaannya, pendidikan disesuaikan dengan kurikulum sekolah dasar pada umumnya hanya materi pelajarannya yang sedikit dikurangi disesuaikan dengan kemampuan anak didik seperti pembelajaran surat-surat pendek seperti surat al-ikhlas, anak tuna rungu cukup diajarkan tulisannya saja sedangkan pada anak tuna grahita cukup diketahui cara membacanya meskipun juga ada yang dapat menghafalkannya. Guru dalam menyampaikan pembelajaran secara umum kepada murid, metode yang sering digunakan adalah metode ceramah dan metode demostrasi, hanya pada anak tuna rungu dibarengi dengan metode oral, metode membaca ujaran, metode isyarat dan komunikasi total, sedangkan untuk anak media pembelajaran tambahan yang digunakan dalam menerapkan pelajaran adalah metode drill dan metode pembelajaran yang diindividualisasikan. Media pembelajaran yang sering digunakan oleh guru pada anak tuna rungu adalah media visual seperti gambar diam, obyek nyata atau bentuk langsung dari suatu benda, sedangkan media pembelajaran pada anak tuna grahita tidak jauh berbeda dengan anak umum lainnya, hanya saja disesuaikan dengan kebutuhan untuk melatih kemampuan murid, contohnya puzzle, atau alat latihan untuk mengurus diri sendiri seperti memasang kancing. Pengamatan : pembelajaran guru dilakukan untuk mengetahui sejauh mana efektivitasnya dalam menyampaikan materi pelajaran sehingga dapat merubah pemahaman anak didik atau ada perubahan pola tingkah laku anak didik setelah guru menyampaikan pembelajaran dengan : tertentu, dari hasil pengamatan tersebut ada motivasi anak didik untuk tetap mengikuti pelajaran.
\end{abstract}

Kata kunci: sekolah luar biasa, pendidikan agama, metode dan media belajar

\begin{abstract}
This study was conducted to identify the implementation of religious education at the school of special educational needs in Pare-Pare particularly for elementary school level with the service types for hearing impairment students and mental retardation students. The religious education adjusted to the elementary school curriculum in general. However, the teaching materials were little bit reduced based on the students capability such as the teaching of short Surah like Surah Al-Ikhlas in which the hearing impairment students were just taught how to write it, but the mental retardation students were taught how to recite it although some were able to memorize it. The instructional methods used by teachers were lecture and demonstration method. However, the hearing impairment students were added with the oral method, the reading utterance method, gesture and total communication methods, while the additional methods for the mental retardation students used in the teaching and learning process were drill methods and the learning methods individualized. The teaching medium frequently used by the teachers for the hearing impairment students was the visual media such as images or the real object. On the other hand, the teaching medium for the mental retardation students was not really different with the normal students in which it was just based on the necessity to train the students' ability
\end{abstract}

Keywords: school of special educational needs, religious education, teaching methods and teaching media 


\section{PENDAHULUAN}

$\mathrm{P}$ endidikan adalah hak seluruh warga Negara dan wajib diberikan kepada peserta didik berdasarkan Undang-Undang Nomor 20 Tahun 2003 tentang Sistem Pendidikan Nasional Bab V, pasal 12 ayat 1 yang berbunyi setiap peserta didik pada satuan pendidikan berhak mendapat : sesuai dengan agama yang dianutnya dan diajarkan oleh pendidik yang seagama. Pada Bab III pasal 4 ayat 1 disebutkan pendidikan diselenggarakan secara demokratis dan berkeadilan serta tidak diskriminatif dengan menjunjung tinggi hak asasi manusia, nilai keagamaan, nilai kultural, dan kemajemukan bangsa. Kemudian pada Bab IV pasal 5 ayat 1 dijelaskan bahwa warga negara yang memiliki kelainan fisik, emosional, mental, intelektual, dan/atau sosial berhak memperoleh pendidikan khusus, dan ayat 2 dijelaskan bahwa warga negara yang memiliki potensi kecerdasan dan bakat istimewa berhak memperoleh pendidikan khusus.

Pemenuhan pendidikan harus diberikan kepada warga Negara tanpa memandang perbedaan status sosial, ekonomi, material, keadaan jasmani atau pun rohani, etnis, dan agama, termasuk mereka yang berkebutuhan khusus, seperti yang memiliki kesulitan belajar, misalnya kesulitan membaca (disleksia), menulis (disgrafia) dan menghitung (diskalkulia) maupun penyandang ketunaan (tuna netra, tuna rungu, tuna grahita, tuna daksa, dan tuna laras) yang semuanya harus diperhatikan dalam mendapatkan dan memenuhi kebutuhan belajarnya.

Dalam pemenuhan pendidikan bagi anak berkebutuhan khusus harus dibedakan dengan anak normal pada umumnya, karena anak berkebutuhan khusus mempunyai perbedaan dalam kemampuan belajar begitupun juga dalam menerima materi pelajaran, dilihat juga dari perkembangan sosioemosionalnya yang berpengaruh pada kemampuan untuk bersosialisasi pada masyarakat sekitar, serta kondisi fisik dan kesehatan yang membuat layanan pendidikan pada anak berkebutuhan khusus bisa menjadi semakin kompleks dan mungkin juga jauh berbeda dengan layanan pendidikan yang didapatkan oleh anak normal pada umumnya. Aspek inilah yang perlu mendapat perhatian dan ditinjau lebih dalam pelaksanaan pendidikan pada Sekolah Luar Biasa (SLB) yang diperuntukkan bagi anak berkebutuhan khusus terutama pada pendidikan agama.

Pelaksanaan pendidikan agama kepada anak berkebutuhan khusus adalah hak yang harus mereka dapatkan dalam rangka peningkatan perkembangan kepribadiannya. Pendidikan agama merupakan sarana utama dalam pembentukannya, melalui pengajaran dan penghayatan, sebagai upaya pembinaan mentalitas iman dalam diri mereka. Pada pelaksanaan pendidikan di SLB, secara umum lebih menekankan pada ranah kognisi dan motorik (keterampilan) peserta didik, ranah kognisi menurut Bloom dalam Makmun (2007: 26) meliputi aspek pengetahuan, pemahaman, penerapan sampai kepada penilaian sedangkan motorik atau ketempilan adalah kegiatan yang berhubungan dengan urat-urat syaraf dan otot-otot yang lazimnya tampak dalam kegiatan jasmaniah seperti menulis, mengetik, olahraga, dan sebagainya (Tohirin, 2005: 94).

Pembelajaran agama yang sifatnya untuk pembekalan kerohanian, cenderung tidak seimbang dengan materi pembelajaran lainnya, bahkan jarang SLB yang memilki guru khusus yang mengajarkan agama, padahal penguatan pembelajaran agama di SLB adalah bahagian dari perluasan akses dan penguatan pendidikan agama di sekolah umum, yang menjadi salah satu prioritas dalam Rencana Strategis Kementerian Agama di bidang pendidikan. Kementerian Agama secara kelembagaan memiliki tanggung jawab dalam pembinaan pendidikan di SLB seperti halnya lembaga pendidikan umum lainnya.

Penelitian-penelitian yang pernah dilakukan yang berhubungan dengan ekolah Luar Biasa dan anak berkebutuhan khusus diantaranya dilakukan oleh peneliti Balai Litbang Agama Semarang tentang Pelaksanaan Pendidikan Agama pada Sekolah di tiga provinsi wilayah kerjanya tahun 2009, yakni Provinsi Kalimantan Barat, Bali, dan Nusa Tenggara Barat. Fokus penelitian adalah tentang Pembelajaran Penndidikan Agama Islam pada SDLB, yang meliputi bagaimana guru menyusun kurikulum, menyusun silabus, menyusun rencana pelaksanaan pembelajaran hingga kegiatan pembelajaran. Dari penelitian tersebut ditelusuri aspek kurikulum pendidikan agama dengan perangkatnya, yang nampaknya belum memiliki dokumen yang memadai. Walaupun dipahami bahwa kurikulum dan penghayatannya adalah salah satu aspek penting dalam pembelajaran. 
Terdapat pula penelitian tentang Pelaksanaan Pendidikan Agama Islam di Sekolah Lua Biasa (Studi Kasus 5 SLB di Jawa Tengah) oleh Tim Peneliti STAIN Kudus yang diterbitkan Puslitbang Pendidikan Agama dan Keagamaan Tahun 2006, merekomendasikan beberapa hal diantaranya banyaknya kendala tentang kurikulum di SLB yang belum sesuai dengan kondisi siswa, maka di sarankan Departemen Agama (Depag) menyusun kurikulum yang lebih sesuai dengan kondisi kecacatan masingmasing; adanya berbagai kekurangan guru di SLB, diharapkan Depag segera merealisasikan pengadaan guru PAI di SLB; diharapkan Depag segera mewujudkan pengadaan buku-buku PAI untuk anak tuna netra yang meliputi Al quran, hadis, sejarah kebudayaan Islam, Baca Tulis Al quran (BTQ), tajwid dan buku-buku lainnya.

Hasil penelitian tersebut menunjukkan bahwa masih terdapat kendala-kendala dalam pelaksanaan pendidikan agama pada sekolah luar biasa. Diantaranya guru bidang studi agama yang masih kurang dan penerapan materi pelajaran yang disesuaikan dengan kompetensi dasar dan standar kompetensi yang belum optimal oleh karena itu penelitian tentang pelaksanaan pendidikan agama pada sekolah luarbiasa masih perlu dilakukan dengan memilih wilayah atau sasaran dan fokus penelitian secara variatif dengan memperhatikan jenjang dan kualifikasi pendidikan untuk mengungkap realitas pelaksanaan pendidikan agama.

Sehubungan dengan kondisi SLB yang telah dipaparkan sebelumnya, maka peneliti fokus pada permasalahan penelitian mengenai bagaimana pelaksanaan pembelajaran pendidikan agama pada Sekolah Luar Biasa dan apa faktor-faktor pendukung dan penghambatnya. Tujuan penelitian ini adalah untuk mengetahui proses pembelajaran pendidikan dan menemukan corak dan model pembelajaran agama pada Sekolah Luar Biasa di provinsi yang diteliti dan untuk mengetahui faktor pendukung dan penghambatnya.

Hasil penelitian ini diharapkan dapat memberikan kontribusi pemikiran kepada pihakpihak terkait, seperti Kementrian Agama, untuk pemberdayaan guru agama dan penataan dokumen pembelajaran pendidikan di sekolah luar biasa, Kementrian Pendidikan dan Kebudayaan sebagai masukan untuk penentuan kebijakan yang berkaitan dengan penguatan pembelajaran pendidikan agama di sekoalah luar biasa, dan pada sekolah luar biasa baik yang diteliti maupun sekolah luar biasa lain mengenai metode dan model pembelajaran pendidikan agama yang efektif agar mudah diserap oleh siswa berkebutuhan khusus tersebut.

\section{Kajian Teori \\ Pendidikan Agama Islam}

Pendidikan agama islam adalah upaya sadar dan terencana dalam menyiapkan peserta didik untuk mengenal memahami, menghayati, hingga mengimani, bertakwa dan berakhlak mulia dalam mengajarkan agama Islam dari sumber utamanya al quran dan hadits, melalui kegiatan bimbingan, pengajaran, latihan serta penggunaan pengalaman (Gunawan, 2012:201). Sedangkan pendidikan agama islam di sekolah diharapkan mampu membentuk kesalehan pribadi atau individu dan kesalehan sosial sehingga pendidikan agama dapat meredam sikap fanatisme, meredam sikap intoleransi di kalangan peserta didik dan masyarakat Indonesia yang dapat memperlemah kerukunan hidup umat beragama yang berdampak pada lemahnya persatuan dan kesatuan nasional.

Pendidikan Islam Merupakan merupakan pendidikan yang harus diberikan pada peserta didik pada semua jenjang dan jalur pendidikan sebagaimana termuat dalam Peraturan Pemerintah Republik Indonesia Nomor 55 Tahun 2007 tentang Pendidikan Agama dan Pendidikan Keagamaan pada pasal 1 ayat (1) Pendidikan agama adalah pendidikan yang memberikan pengetahuan dan membentuk sikap, kepribadian, dan keterampilan peserta didik dalam mengamalkan ajaran agamanya, yang dilaksanakan sekurang-kurangnya melalui mata pelajaran/kuliah pada semua jalur, jenjang, dan jenis pendidikan.

Ayat (2) pendidikan keagamaan adalah pendidikan yang mempersiapkan peserta didik untuk dapat menjalankan peranan yang menuntut penguasaan pengetahuan tentang ajaran agama dan menjadi ahli ilmu agama dan mengamalkan ajaran agamanya. Kemudian pada pasal 3 ayat (1) disebutkan bahwa setiap satuan pendidikan pada semua jalur, jenjang, dan jenis pendidikan wajib menyelenggarakan pendidikan. Lanjut pada pasal 4 ayat (1) dan (2) disebutkan bahwa pendidikan agama pada pendidikan formal dan program pendidikan kesetaraan sekurang-kurangnya diselenggarakan dalam bentuk mata pelajaran atau mata kuliah agama. Dan setiap peserta didik pada satuan pendidikan di semua jalur, jenjang, dan jenis pendidikan berhak mendapat pendidikan 
agama sesuai agama yang dianutnya dan diajar oleh pendidik yang seagama.

Tujuan pendidikan adalah untuk menumbuhkan dan meningkatkan keimanan, melalui pemberian dan pemupukan pengetahuan, penghayatan serta pengalaman peserta didik tentang agama Islam sehingga menjadi manusia muslim yang terus berkembang dalam hal keimanan, ketakwaannya kepada Allah swt, serta berakhlak mulia dalam kehidupan pribadi, bermasyarakat, berbangsa dan bernegara, serta untuk dapat melanjutkan pada jenjang pendididkan yang lebih tinggi (Depdiknas, 2006).

Pendidikan Agama Islam di SDLB bertujuan untuk menumbuh kembangkan aqidah melalui pemberian, pemupukan, dan pengembangan pengetahuan, penghayatan, pengamalan pembiasaan, serta pengamalan peserta didik tentang agama Islam sehingga menjadi manusia muslim yang terus berkembang keimanan dan ketakwaannya kepada Allah swt., dan mewujudkan manusia Indonesia berakhlak mulia yaitu manusia yang produktif, jujur, adil, etis, berdisiplin, bertoleransi (tasamuh), serta menjaga harmoni secara personal dan sosial. (Depdiknas, 2006).

\section{SLB dan Anak Berkebutuhan Khusus}

Sekolah Luar Biasa adalah sekolah yang menyelenggarakan pembelajaran terhadap anakanak berkebutuhan khusus, disebabkan olah kekurangan kesempurnaan keadaan fisik maupun mental mereka, sehingga mereka menyandang ketunaan. anak berkebutuhan khusus (ABK) adalah anak yang mempunyai gangguan perkembangan baik fisik, mental, sosial, atau emosional dan gangguan belajar sehingga memerlukan penanganan atau layanan secara khusus di sekolah. Karena adanya gangguan ini maka anak berkebutuhan khusus mengalami kesulitan dalam belajarnya sehingga mempengaruhi pembelajarannya (barrier of learning) dan akibatnya mereka memiliki kebutuhan belajar (learning needs) yang berbeda dengan yang lainnya (Kustawan, 2012: 8).

Anak didik berkebutuhan khusus ada sifatnya permanen atau menetap dan ada yang sifatnya temporer atau sementara, anak berkebutuhan khusus yang sifatnya permanen adalah anak yang memiliki tingkat kesulitan dalam mengikuti proses pembelajaran karena kelainan fisik, emosional, mental, intelektual, sosial dan memiliki potensi kecerdasan dan bakat istimewa sehingga mereka memerlukan pendidikan Khusus (PK). Sedangkan anak berkebutuhan khusus yang sifatnya sementara adalah anak memiliki kesulitan belajar yang disebabkan oleh faktor lingkungan atau dari luar dirinya seperti tinggal di daerah terpencil, anak yang terkena bencana alam dan bencana sosial sehingga memerlukan pendidikan Layana Khusus (PLK).

Peserta didik anak berkebutuhan khusus diantaranya adalah peserta didik tuna rungu adalah peserta didik yang memiliki hambatan pendengaran (hearing impaired). Klasifikasi tuna rungu dapat digolongkan yaitu tuna rungu ringan (mild hearing loss), adalah tuna rungu yang mengalami kehilangan pendengaran antara 27-40 dB. tuna rungu sedang (moderate hearing loss), adalah tuna rungu yang mengalami kehilangan pendengaran antara 41$55 \mathrm{~dB}$. Tuna rungu agak berat (moderately severe hearing loss), adalah tuna rungu yang mengalami kehilangan pendengaran antara 56-70 $\mathrm{dB}$. tuna rungu berat (severe hearing loss), adalah tuna rungu yang mengalami kehilangan pendengaran antara 71-90 dB. tuna rungu berat sekali (profound hearing loss), adalah tuna rungu yang mengalami kehilangan pendengaran lebih dari $90 \mathrm{~dB}$ (Wardani, 2009).

Peserta didik tuna grahita adalah peserta didik yang memiliki intelegensia yang signifikan berada di bawah rata-rata atau di bawah normal dan disertai dengan ketidakmampuan dalam adaptasi perilaku yang muncul dalam masa perkembangan atau biasa dinilai dari tingkat kecerdasannya atau IQ di bawah rata-rata dari tingkat kecerdasan anak normal. Klasifikasi tuna grahita dapat digolongkan dalam tuna grahita ringan (mild mental retardation), yaitu tuna grahita yang memiliki IQ 70-55. Tuna grahita sedang (moderate mental retardation), yaitu tuna grahita yang memiliki IQ 55-40. Tuna grahita berat (severe mental retardation), yaitu tuna grahita yang memiliki IQ 40-25. Tuna grahita sangat berat (profound mental retardation), yaitu tuna grahita yang memiliki IQ 25 ke bawah.

Peserta didik tuna netra adalah peserta didik yang memiliki hambatan dalam penglihatan. Klasifikasi tuna netra dapat digolongkan berdasarkan tingkat ketajaman penglihatan yaitu low vision/ partially sighted (kurang lihat), adalah tuna netra dengan ketajaman penglihatan $6 / 20 \mathrm{~m}-6 / 60 \mathrm{~m}$ atau 20/70 feet-20/200 feet, blind (buta), adalah tuna netra dengan ketajaman penghlihatan antara $6 / 60 \mathrm{~m}$ atau 20/200 feet atau kurang dari angka tersebut, totally blind (buta total), adalah tuna netra dengan 
ketajaman penglihatan visus 0 . Berdasarkan saat terjadinya yaitu tuna netra sebelum dan sejak lahir, tuna netra balita, tuna netra pada usia sekolah, tuna netra remaja dan tuna netra remaja. Berdasarkan adaptasi pendidikan yaitu ketidakmampuan melihat taraf sedang (moderate visual disability), ketidakmampuan melihat taraf berat (severe visual disability), ketidakmampuan melihat taraf sangat berat (profound visual disability) (Wardani, 2009).

\section{Strategi dan Model Pembelajaran}

Strategi dan model pembelajaran adalah bagian dari proses pembelajaran yang bertujuan untuk meningkatkan kualitas pembelajaran menjadi lebih baik dan peserta didik mampu menerima pelajaran dengan baik begitupun juga dengan pendidik mampu menyampaikan materi pembelajaran secara efektif dan efesien. Strategi pembelajaran menurut Kemp dalam Gunawan (2012) adalah suatu pembelajaran yang harus digunakan oleh guru dan peserta didik agar tujuan pembelajaran dapat dicapai secara efektif dan efesien. Senada dengan Kemp, Dick dan Carey masih dalam Gunawan (2012) juga menyebutkan bahwa strategi pembelajaran itu adalah suatu perangkat materi dan prosedur pelajaran yang digunakan secara bersamasama untuk mencapai hasil belajar pada peserta didik.

Sedangkan menurut Ambarjaya, strategi pembelajaran merupakan suatu rencana tindakan (rangkaian kegiatan) yang termasuk juga penggunaan metode dan pemanfaatan berbagai sumber daya dalam pembelajaran. Jadi untuk merealisasikan strategi pembelajaran yang ditetapkan maka diperlukan metode sebagai upaya untuk mengimplementasikan rencana pembelajaran yang telah disusun dalam kegiatan nyata agar tujuan yang telah disusun dapat tercapai secara optimal (Ambarjaya, 2012: 84).

Dengan demikian bisa terjadi satu strategi menggunakan beberapa metode, misal untuk melaksanakan strategi ekspositori bisa digunakan metode caramah sekaligus metode tanya jawab atau bahkan diskusi dengan memanfaatkan sumber daya yang tersedia termasuk menggunakan media pembelajaran. Oleh sebab itu, strategi berbeda dengan metode, strategi menunjukkan pada sebuah perencanaan untuk mencapai sesuatu sedangkan metode adalah cara yang dapat digunakan untuk melaksanakan strategi.
Strategi pembelajaran pada anak berkebutuhan khusus hampir sama dengan strategi pembelajaran yang digunakan pada anak normal umumnya, hanya terdapat beberapa strategi khusus yang dapat diterapkan yaitu misalnya pada anak tuna rungu digunakan strategi individualisasi, strategi kooperatif dan strategi modifikasi prilaku (Wardani, 2009). Strategi Individualisasi biasanya dikenal dalam Program Pendidikan Individualisasi (PPI) atau biasa disebut Individualized Educational Program (IEP) yaitu strategi pembelajaran yang mempergunakan suatu program yang disesuaikan dengan perbedaan-perbedaan individu baik karakteristik, kebutuhan maupun kemampuannya secara perorangan. Strategi kooperatif adalah strategi pembelajaran yang menekankan pada sikap saling membantu dengan teman lainnya, dan akan berjalan efektif bila diterapkan pada kelompok anak didik yang mempunyai kemampuan heterogen. Strategi modifiakasi perilaku adalah strategi yang digunakan untuk mengubah perilaku siswa kearah yang lebih baik.

Model pembelajaran sangat penting dilakukan dalam rangka mencapai tujuan pembelajaran. Tujuan pembelajaran perlu ditetapkan agar target yang diharapkan dari kurikulum dapat tercapai dengan memperhatikan kemampuan yang dimiliki oleh peserta didik. Untuk jangka pendek, tujuan pembelajaran adalah tujuan pembelajaran yang hendak dicapai dalam waktu yang relatif singkat, seperti target pembelajaran pada : Dasar (KD). Sedang untuk jangka panjang, tujuan pembelajaran adalah tujuan yang hendak dicapai pada waktu yang relative lama, seperti target yang tertera pada Standar : (SK) (Triani, 2012: 24).

Para ahli pendidikan, terutama pemerhati ilmu pembelajaran, mengembangkan berbagai model pembelajaran yang diaplikasikan dalam berbagai bidang pembelajaran. Salah satu diantaranya adalah pendekatan pembelajaran individu, didalamnya dikembangkan model pembelajaran yang diasumsikan dapat diterapkan di SLB. Model-model pembelajaran tersebut adalah model pembelajaran tidak langsung (non directive teaching), model ini dikembangkan oleh Carl Roger, mengaplikasikannya dalam strategi konseling pembelajaran. Diyakini bahwa hubungan yang positif dapat membantu individu berkembang. Karena itu pengajaran harus didasarklan atas hubungan yang positif, tujuan utamanya adalah membantu siswaa mencapai 
integritas dan efektivitas pribadi dan penghargaan terhadap dirinya secara realistis, perang guru dalam model ini adalah sebagai pasilitator.

Model pembelajaran pelatihan kesadaran (awarenes training), model ini ditujukan untuk meningkatkan kesadaran manusia, dipelopori oleh Miliam Schutz yang menekankan pentingnya pelatihan interpersonal sebagai sarana peningkatan kesadaran pribadi. Menurutnya ada empat tipe perkembangan yang dibutuhkan untuk merealisasikannya yaitu: fungsi tubuh; fungsi personal akuisisi pengetahuan dan pengalaman; kemampuan berpikir logis; serta kereatif, integrasi, intelektual, dan hubungan institusi sosial. Tujuannya adalah untuk meningkatkan pemahaman diri dan kesadaran akal perilaku diri sendiri dan perilaku orang lain.

Model pembelajaran pertemuan kelas, model ini diciptakan berdasarkan terapi realitas, dipelopori oleh William Glasser kemudian diaplikasikan dalam pengajaran. Glasser percaya bahwa permasalahan manusia kebanyakan disebabkan oleh kegagalan memfungsikan diri dalam lingkungan sosialnya. Kebutuhan dasarnya adalah cinta dan harga diri. Glasser mengaplikasikannya untuk pembelajaran di kelas. Tujuannya adalah untuk membangun suatu kelompok sosial yang saling mencintai, saling menyayangi, mempunyai kedisiplinan diri dan komitmen untuk berperilaku positif (Hamzah, 2008: 18).

\section{METODOLOGI PENELITIAN}

Lokasi penelitian ini adalah Sekolah LuarBiasa (SLB) Negeri Parepare dengan sasaran jenjang Pendidikan sekolah dasar atau SDLB dengan pelayanan tuna rungu (B) dan tuna grahita (C). Penelitian ini menggunakan pendekatan kualitatif yang menguraikan data yang berbentuk deskriptif dengan menggambarkan fenomena yang diteliti. Penelitian ini mencoba memperoleh gambaran jelas tentang keterlaksanaan pembelajaran pendidikan di SLB, kualifikasi dan kompetensi guru agama di SLB, dengan tetap memperhatikan kualifikasi dan kompetensi guru agama tersebut.

Selain itu gambaran lain yang ingin diketahui adalah mengenai faktor pendukung dan penghambat dalam penerapan metode pembelajaran agama di SLB. Prosedur penelitian ini adalah dengan cara melakukan interpretasi terhadap deskriptif studi lapangan berupa perilaku para guru agama Islam yang mengajar di SLB baik yang tertulis, terucap maupun tingkah laku guru agama dalam mengajar Pendidikan Agama di SLB tersebut. Setelah itu peneliti melakukan analisis untuk kemudian membuat generalisasi terhadap metode pengajaran para guru agama di Sekolah Luar Biasa tersebut.

Data yang diperoleh dalam penelitian ini dibagi menjadi dua yaitu sumber primer dan sekunder. Sumber primer adalah yang berhubungan langsung dengan objek penelitian yaitu pendidik (guru) mata pelajaran pendidikan agama yang mengajar di SLB itu sendiri, kepala SLB, dan guru kelas. Sedangkan sumber sekunder adalah dokumentasi atau dokumen-dokumen seperti dokumen keadaan sekolah (fisik, ketenagaan, visi misi, ataupun profil SLB dokumen kurikulum dan muatan kurikulum, silabus dan rencana pelaksanaan pembelajaran, dan lain-lain, diinternal SLB. Dan juga dokumen pendukung seperti data kependudukan, kelembagaan pendidikan yang dapat diperoleh pada BPS dan Dinas Pendidikan dan Kebudayaan Provinsi, Kabupaten, dan Kota.

Teknik yang digunakan dalam pengumpulan data yaitu, teknik observasi (pengamatan) yang difokuskan pada SLB. Teknik ini digunakan untuk mengumpulkan data dan gambaran umum yang meliputi letak geografis, sarana dan prasarana, keadaan guru dan siswa media, dan sumber belajar. Pengamatan letak geografis ini bertujuan untuk mengetahui posisi sekolah dilihat dari tempat tinggal peserta didik. Pengamatan sarana dan prasarana dilakukan untuk mengetahui sarana-sarana apa saja yang ada di SLB tersebut dalam menunjang pembelajaran siswa, sedangkan pengamatan guru dan siswa digunakan untuk mengetahui kedekatan guru agama dengan peserta didiknya. Dekat atau tidaknya pendidik dengan peserta didik menurut peneliti akan berpengaruh dalam proses pembelajaran pendidikan agama.

Di samping itu, pendekatan ini dapat digali mengenai data bentuk-bentuk komunikasi yang dibangun guru kepada siswanya. Kemudian teknik wawancara yang digunakan untuk memperoleh data mendalam mengenai metode atau model pembelajaran pendidikan agama yang dilakukan oleh guru agama di SLB. Teknik ini digunakan juga untuk menggali faktor pendukung serta faktor penghambat selama proses belajar mengajar pendidikan agama di SLB. Hasil wawancara kemudian dicatat untuk kemudian dilakukan reduksi dan mengkategorikan data.

Data-data yang sejenis akan dikelompokan menjadi satu. Dan teknik dokumentasi, yaitu metode 
dokumentasi yang digunakan untuk memperoleh dokumen-dokumen penting yang terkait dengan pelaksanaan pendidikan agama di SDLB. Dokumendokumen tersebut meliputi sejarah SDLB, Tujuan pendirian sekolah, visi sekolah, kurikulum serta muatan kurikulum pendidikan. Selain itu melalui teknik dokumentasi ini akan digali mengenai jumlah siswa secara keseluruhan dan murid yang beragama Islam dan selainnya.

Terhadap teknik pengumpulan data di atas, di catat dalam catatan lapangan dan catatan reflektif yang dilakukan peneliti setiapkegiatan pengumpulan data. Sedangkan analisis data dilakukan sesuai dengan prosedur dan teknik-teknikyang lazim dalam penelitian dengan memperlihatkan bentuk dan sifat data yang terkumpul. Data yang bersifat kuantitatif ditabulasi atau dipresentasikan. Sedangkan data yang bersifat kualitatif disajikan secara deskriptif kualitatif. Keseluruhan data, disajikan secara naratif sesuai proporsi masing-masing data.

\section{PEMBAHASAN}

\section{SLB Negeri Parepare}

SLB Negeri Parepare terdiri dari tingkat pendidikan TKLB, SDLB, SMPLB, SMALB yang berstatus negeri dengan NPWP sekolah 00.649.950.3-802.000, kelompok sekolah adalah SLB inti, nomor statistik sekolah 101196102035, alamat sekolah kelurahan Bukit Harapan kecamatan Soreang kota Parepare Provinsi Sulawesi Selatan, telah terakreditasi pada tahun 2005 (nilai 80) dengan predikat baik dan tahun 2007 (nilai 80,5) predikat baik, tahun berdiri 1989 .

Visi SLB Negeri Parepare adalah mengembangkan sisa kemampuan peserta didik agar menjadi yang berprestasi, terampil, dan bertakwa. Sedangkan misi SLB Negeri Parepare adalah meningkatkan ketakwaan terhadap kebesaran Tuhan Yang Maha Esa, mengembangkan pengetahuan, sikap, dan psikomotor peserta didik melalui formal di sekolah, menanamkan konsep diri yang positif agar beradaptasi dan diterima dalam bersosialisasi di masyarakat, membangun citra sekolah sebagai mitra terpercaya di masyarakat. Adapun tujuan SLB Negeri Parepare adalah mengembangkan kemampuan peserta didik dalam berinteraksi secara vertikal dan horizontal, meningkatkan pemahaman sehingga mandiri berprestasi dalam masyarakat luas dan negara, mempersiapkan peserta didik untuk melanjutkan kejenjang yang lebih tinggi disemua sektor atau bidang berdasarkan jenis kecacatan dan kemampuannya.
Ketenagaan pada SLB Negeri Parepare adalah ketenagaan guru atau pelaksana pembelajaran dan ketenagaan administrasi sebagai pengelola sekolah atau pendukung terlaksananya proses pembelajaran di sekolah. Guru yang bertugas pada SLB Negeri Parepare terdiri dari guru kelas dan guru mata pelajaran. Guru kelas adalah tenaga pendidik atau pengajar pada suatu kelas yang telah ditentukan di SLB Negeri Parepare yang dipersyaratkan berdasarkan kualifikasi yang dimiliki, bertanggung jawab atas pengelolaan pembelajaran dan adiministrasi di kelasnya. Kelas yang dibimbing ditetapkan berdasarkan kebutuhan sekolah, jadi sifatnya tidak menetap, dapat berubah-rubah pada setiap tahun pelajaran sesuai dengan kondisi sekolah. Sedangkan guru mata pelajaran adalah guru yang mengajar mata pelajaran tertentu sesuai kualifikasi yang dipersyaratkan.

Pada SLB Negeri Parepare mata pelajaran tertentu adalah pendidikan agama, pendidikan jasmani dan kesehatan, mata pelajaran bahasa Inggris. Tugas guru kelas dan guru mata pelajaran pada SLB Negeri Parepare tidak begitu berbeda dengan tugas guru kelas dan guru mata pelajaran yang ditetapkan pada pedoman pengadaan dan pembinaan tenaga pendidik oleh Direktorat Pembinaan Sekoalah Luar Biasa Departemen Pendidikan Nasional Tahun 2007.

Tugas guru kelas antara lain adalah menciptakan iklim belajar yang kondusif sehingga anak-anak merasa nyaman belajar di kelas, menyusun dan melaksanakan asesmen pada semua anak untuk mengetahui kemampuan dan kebutuhannya, menyusun Program Pembelajaran Individual (PPI), melaksanakan kegiatan belajar-mengajar dan mengadakan penilaian untuk semua mata pelajaran (kecuali pendidikan agama, pendidikan jasmani dan kesehatan, serta bahasa Inggris) yang menjadi tanggung jawabnya, memberikan program remedial pengajaran (remedial teaching), pengayaan bagi peserta didik yang membutuhkan, melaksanakan administrasi kelas sesuai dengan bidang tugasnya.

Sedangkan tugas guru mata pelajaran antara lain adalah menciptakan iklim belajar yang kondusif sehingga anak-anak merasa nyaman belajar di kelas, menyusun dan melaksanakan asesmen pada semua anak untuk mengetahui kemampuan dan kebutuhannya, menyusun Program Pembelajaran Individual (PPI), melaksanakan kegiatan belajarmengajar dan mengadakan penilaian kegiatan belajar mengajar untuk mata pelajaran yang 
menjadi tanggung jawabnya, memberikan program perbaikan (remedial teaching), pengayaan bagi peserta didik yang membutuhkan. Adapun jumlah ketenagaan guru pada SLB Negeri Parepare adalah 8 orang PNS dan 2 orang non-PNS, sedangkan ketenagaan administrasi terdiri dari 1 orang kepala sekolah, 3 orang Tata Usaha, 1 orang pengelola perpustakaan, dan 1 orang bujang sekolah.

Menurut keterangan kepala sekolah $(\mathrm{Hj}$. Naslah, S.Pd) bahwa jumlah siswa yang belajar pada SLB Negeri Parepare sebanyak 58 orang yang terdiri dari jenjang SDLB sebanyak 44 orang, jenjang SMPLB sebanyak 11 orang dan jenjang SMALB sebanyak tiga orang. Siswa yang tamping di SLB Negeri Parepere berasal dari kota Parepare dan di luar kota Parepare atau kabupaten lain, seperti Pinrang, Polman, Pangkep Barru, Sidrap dan lain sebagainya.

Siswa yang berasal dari luar daerah atau tempat tinggalnya jauh dari sekolah, ditempatkan di asrama sekolah yang berlokasi di dalam area sekolah, meskipun begitu menurut Bapak Muh.Sabri (guru kelas tuna grahita) bahwa siswa yang akan di asramakan, terlebih dahulu diseleksi, minimal siswa tersebut telah mampu mengurus dirinya dan sudah bisa melakukan rutinitas keseharian seperti mandi, makan minum, berpakaian, merapikan tempat tidur, membersihkan kamar dan lain sebagainya. Seleksi ini perlu dilakukan agar asrama sekolah tidak terkesan seperti tempat penitipan anak. Selain tinggal di asrama sekolah, anak yang berasal dari luar daerah ada juga yang tinggal bersama kelurganya yang bertempat tinggal di dekat sekolah atau tinggal bersama saudaranya yang menempuh pendidikan pada Sekolah Tinggi Agama Islam Negeri (STAIN) Parepare (letak STAIN dan SLB Parepare berdekatan).

Selain menempuh kegiatan belajar di sekolah, kegiatan ekstrakurikuler juga diperkenalkan seperti pramuka, baris berbaris, unit kesehatan sekolah dan kegiatan keterampilan. Menurut Hj. Naslah, keterampilan yang diberikan kepada siswa adalah keterampilan yang betul-betul tidak memberatkan siswa dan disesuaikan dengan bakat dan minat siswa sehingga dapat menggali aspek psikomotorik dalam memberikan pendidikan. Keterampilan tersebut antara lain keterampilan menggambar, melukis, tata rias dan kecantikan, serta keterampilan hantaran (dekor pengantin).

Dari kegiatan ekstrakurikuler dan keterampilan tersebut dapat menumbuhkan rasa percaya diri siswa dalam bersosialisasi baik di sekolah dengan teman-teman dan guru, di keluarga maupun berinteraksi di lingkungan masyarakat sehingga apabila diikutkan lomba atau porseni dikalangan Sekolah Luar Biasa dapat memberikan prestasi yang baik dan memuaskan.

Prestasi yang dicapai oleh siswa SLB Negeri Parepare dari beberapa kegiatan perlombaan dan porseni yang diikuti baik tingkat lokal, provinsi maupun tingkat nasional sangat membanggakan, hal ini terlihat dari banyaknya penghargaan yang telah diperoleh diantaranya juara I lomba melukis tingkat nasional disabilitas tuna rungu, juara harapan I cerdas cermat tingkat nasional disabilitas tuna daksa, juara baris berbaris tingkat provinsi dan nasional yang tiap tahun diikuti, juara pantomim, juara olahraga atletik seperti lari, melempar dan sebagainya. Materi keterampilan yang didapatkan anak didik berasal dari sekolah dan terdapat pula pembimbingan khusus untuk mempermantap keterampilan yang diminati siswa.

\section{Pelaksanaan Pendidikan Agam \\ Kurikulum}

Kurikulum yang digunakan pada SLB Negeri Parepare khususnya pada jenjang SDLB sama seperti yang digunakan pada sekolah umum lainnya, pernyataan ini diungkapkan oleh Ibu Suarni, S.Pd. (guru kelas tuna rungu), hal senada juga diungkapkan oleh Ibu Normayanti, S.Pd.I (guru mata pelajaran agama) bahwa kurikulum yang digunakan juga mengacu pada kurikulum sekolah umum hanya saja materinya agak dikurangi disesuaikan dengan kondisi siswa seperti pembelajaran surat-surat pendek seperti surat $\mathrm{Al}$ Ikhlas, anak tuna rungu cukup diajarkan tulisannya saja sedangkan pada anak tuna grahita cukup diketahui cara membacanya meskipun juga ada yang dapat menghafalkannya.

Meskipun mengikuti kurikulum seperti pada sekolah umum, tetap saja ada mata pelajaran tambahan yang diberikan pada murid SLB Negeri Parepare yang disesuaikan dengan kebutuhan khusus anak. Misalnya pada anak tuna netra diberikan pelajaran tambahan seperti Orientasi Mobilitas (OM) yaitu pengenalan lingkungan, anak didik dibimbing untuk mengenali dan berinteraksi dengan lingkungan sekitar dengan tujuan untuk menumbuhkan dan mengembangkan kemandiriannya contohnya mencari benda-benda, mengetahui jenis dan letak benda-benda yang ada 
diruangan kelas sampai kepada tata ruang disekitar sekolah maupun di rumahnya.

Untuk anak tuna rungu diberikan pelajaran tambahan BPBI yaitu artikulasi bahasa isyarat seperti huruf abjad yang dilambangkan dengan isyarat tangan menggunakan kombinasi bentuk jari tangan dan artikulasi umum lainnya dalam kehidupan sehari seperti ibu, bapak, adik, rumah, sekolah, mandi, makan minum, belajar, shalat, pulang ke rumah, pergi ke sekolah dan lain sebagainya. Untuk anak tuna grahita diberikan pelajaran tambahan seperti merawat diri, pakai baju dan sebagainya karena anak tuna grahita mempuyai mental dan kondisi kejiwaan yang tidak sama dengan anak normal sehingga terkadang pekerjaan rutinitas keseharian belum bisa dikerjakan sendiri seperti pada anak normal seusianya. Sedangkan pada anak : diberikan pelajaran tambahan bina gerak seperti latihan jalan, belajar menggerakkan anggota badan dengan gerakan tertentu.

Kurikulum SLB mata pelajaran pendidikan agama, pendidikan kewarganegaraan, bahasa Indonesia, matematika, ilmu pengetahuan alam, ilmu pengetahuan sosial, seni budaya dan keterampilan, pendidikan jasmani olahraga dan kesehatan, muatan lokal, program khusus bina komunikasi, persepsi bunyi dan irama (untuk tuna rungu), program khusus bina diri atau kemampuan merawat diri (untuk tuna grahita), pengembangan diri. Untuk materi pelajaran pendidikan agama pada SDLB Negeri Parepare kelas II adalah melafalkan dan membaca Al quran surat-surat pendek pilihan, mengenal asmaul husna, mencontohkan perilaku terpuji, mengenal tata cara berwudhu, melafalkan dan membiasakan secara tertib bacaan shalat.

Untuk kelas $\mathrm{V}$ meteri pelajarannya adalah membaca $\mathrm{Al}$ quran surat-surat pendek pilihan (An-Naas, Al-Ikhlas, Al-Falaq, dan Al-Lahab), mengenal kitab-kitab Allah swt, mengenal rukun Islam, membiasakan perilaku terpuji, membiasakan tata cara berwudhu secara tertib, serta adzan dan iqamah.

\section{Metode Pembelajaran}

Metode adalah sebuah cara yang dipergunakan guru secara efektif dan efesien dalam mengadakan hubungan (pembelajaran) dengan peserta didik, pada saat berlangsungnya proses pembelajaran untuk mencapai tujuan pembelajaran. metode yang digunakan dalam proses belajar mengajar adalah metode ceramah (lecture method) dan metode demostrasi (demonstration method). metode ceramah adalah cara penyajian pelajaran atau penyampaian keterangan atau informasi ataupun penjelasan dari pokok persoalan melalui penuturan secara lisan (verbal) atau penjelasan langsung kepada peserta didik (Gunawan, 2012).

Metode ceramah ini adalah cara yang paling sering digunakan oleh guru dalam menyampaikan pembelajaran baik di dalam kelas maupun di luar kelas atau biasa disebut dengan cara klasik. Sedangkan metode demonstrasi adalah metode pembelajaran yang dilakukan dengan menunjukkan peragaan langsung kepada peserta didik mengenai cara melaksanakannya. Terdapat pula penekanan praktik terhadap materi pembelajaran yang dilakukan langsung oleh guru dan peserta didik. Contohnya cara melakukan gerakan-gerakan berwudhu, guru mempraktikkan langsung kepada siswa atau menyuruh salah seorang siswa untuk mempraktikkannya dan siswa yang lain mengikutinya sehingga siswa akan cepat beradaptasi dengan gerekan-gerakan yang telah dipraktikkan.

Selain metode tersebut di atas, menurut Ibu Suarni juga terdapat metode lain yang digunakan dalam menerapkan pembelajaran pada anak tuna rungu, metode tersebut adalah metode oral, metode membaca ujaran (speech reading), metode isyarat dan komunikasi total, dengan pengertian metode oral, adalah metode berkomunikasi melalui bahasa lisan, yang dilakukan dengan pembentukan dan latihan bicara (speech building dan speech training) serta latihan pendengaran (hear training). metode membaca ujaran (speech reading), yaitu mengajarkan anak tina rungu bacaan atau sebutan melalui gerak bibir dan mimik, anak tuna rungu dituntun untuk mengikuti bacaan tersebut dan dilakukan secara berulang-ulang, sehingga dipersyaratkan guru tidak terlalu jauh jaraknya dengan murid dan harus berhadapan langsung (face to face).

Tetapi metode ini terdapat kekurangan, yaitu ketika organ artikulasi (gerakan mulut) menyebutkan huruf $\mathrm{k}, \mathrm{x}$ dan $\mathrm{s}$, atau misalnya terdapat kesamaan bunyi bahasa bila terdapat huruf bilabial (p, b, m) dan huruf dental ( $d, t, n$ ) yang ketika diucapkan bahasanya akan terlihat sama bentuknya pada bibir. metode isyarat, biasa juga disebut metode manual, yaitu metode komunikasi dengan menggunakan bahasa isyarat dan ejaan jari (finger spending). Contohnya abjad jari (finger spelling), bahasa tubuh, atau bahasa isyarat asli. komunikasi total, yaitu gabungan dari beberapa metode komunikasi seperti 
metode membaca ujaran, metode isyarat dan bahasa tubuh. Metode ini yang paling sering digunakan karena sedikit lebih mempermudah anak tuna grahita dalam menangkap komunikasi (Wardani. dkk, 2009).

Metode oral digunakan hampir pada setiap pertemuan, misalnya dalam memberi salam Ibu guru biasanya membesarkan suaranya dengan tujuan untuk meransang pendengaran murid dan membiasakan untuk latihan mengucapkan kata 'salam'. Sedangakan metode membaca ujaran terlihat ketika peneliti mengobsevasi cara mengajar Ibu Suarni masuk ke ruangan kelas, Ibu Suarni memperkenalkannya kepada murid dengan menyebutkan kata 'bapak' disertai dengan gerak atau mimik bibir dan dicontohkan kepada siswa, Ibu Suarni mencontohkannya dengan menuntun menyebutkan (baa...paa) dan murid juga mengikutinya dengan sedikit demi sedikit berujar (bbb...pa'). metode isyarat digunakan oleh Ibu Suarni ketika mengajarkan agama menggunakan isyarat jari tangan untuk kata 'agama' kepada murid dengan gerak bahasa tubuh menunjuk ke atas.

Metode komunikasi total digunakan oleh Ibu Suarni dan Ibu Normayanti ketika murid diperintahkan untuk mempratikkan cara berwudhu, Ibu Suarni memanggil salah seorang murid dengan menggunakan isyarat kemudian menyampaikan bahwa -kita akan mempraktekkan tata cara berwudhu dengan gerak bibir sambil menggerak-gerakkan tangan sebagai tanda kita akan berwudhu. Sedangkan untuk anak tuna grahita metode tambahan yang digunakan dalam menerapkan pelajaran adalah metode drill dan metode pembelajaran yang diindividualisasikan. metode drill adalah menuntun murid untuk malaksanakan suatu kegiatan atau latihan suatu hal yang sama secara berulang-ulang dengan tujuan siswa memiliki keterampilan yang meningkat dan bersifat permanen.

metode pembelajaran yang diindividualisasikan artinya metode pengajaran yang diberikan pada tiap murid meskipun mereka belajar bersama pada ruangan dan mata pelajaran yang sama, tetapi bobot atau kedalaman dan keluasan materi pelajaran disesuaikan dengan kemampuan dan kebutuhan bagi tiap siswa. Contoh dari penerapan metode drill ini adalah ketika murid (Andi Suryani) diperintahkan untuk mempraktikkan tata cara berwudhu, pada saat ditreatment mencuci tangan dan membasuh muka dilakukan secara berulangulang agar bisa lebih baik.

\section{Media Pembelajaran}

Media pembelajaran adalah perangkat yang digunakan untuk menyampaikan pelajaran yang dapat menciptakan kondisi yang memungkinkan murid memperoleh, pengetahuan, keterampilan, dan perubahan sikap. Media juga merupakan salah satu strategi untuk meransang minat dan perhatian anak didik seperti transparansi, film atau video, dan tape recorder (Syatra, 2013). Untuk anak tuna rungu, media pembelajaran yang umumnya digunakan adalah media visual seperti gambar diam (still picture), gambar bergerak (motion pictures), grafik, bagan, diagram, dan obyek nyata atau bentuk langsung dari suatu benda. Media visual adalah media yang hanya dapat dilihat dengan menggunakan indera penglihatan (Gunawan, 2012: 187). Media audio seperti program suara tiruan untuk melatih membeda-bedakan suara. Media audio adalah media yang mengandung pesan dalam bentuk auditif yang dapat meransang pikiran, perasaan, perhatian, dan kemauan para siswa untuk mempelajari bahan ajar. Media audio-visual seperti program video atau televisi instruksional. Tetapi media ini banyak digunakan pada anak tuna rungu ringan atau masih mempunyai sisa pendengaran yang cukup dan menggunakan alat bantu dengan (hearing aids).

Sedangkan media pembelajaran pada anak tuna grahita tidak jauh berbeda dengan anak umum lainnya, hanya saja disesuaikan dengan kebutuhan untuk melatih kemampuan murid, contohnya alat untuk melatih kemampuan motorik seperti form board, puzzle, alat latihan untuk mengurus diri sendiri seperti memasang kancing, memasang retsleting dan lain sebagainya.

\section{Pengamatan Metode Pembelajaran Guru}

Pengamatan ini dilakukan untuk mengetahui sejauh mana efektivitas metode pembelajaran guru dalam menyampaikan materi pelajaran sehingga dapat merubah pemahaman anak didik atau ada perubahan pola tingkah laku anak didik setelah guru menyampaikan pembelajaran dengan metode tertentu, pengamatan dilakukan dengan memanggil salah seorang anak didik untuk mempraktikkan materi pelajaran yang diberikan. Materi pembelajaran yang diberikan yaitu mendefenisikan 
materi pelajaran, menyebutkan urutan-urutan materi pelajaran, menjawab dan melaksanakan tugas guru, menyelesaikan materi pelajaran dengan urut, melaksanakan materi pelajaran dengan benar, menyelesaikan semua materi pelajaran.

Anak didik diperintahkan untuk mendefenisikan tentang tata cara berwudhu, anak tersebut tahu tentang berwudhu tetapi dalam menjelaskan materi pelajaran belum mampu untuk memberikan gambaran secara jelas hanya beberapa tahap yaitu bahwa ketika kita akan melaksanakan shalat maka kita harus berwudhu dulu, begitupun dengan menyebutkan urutan materi pelajaran, sebelum diberikan gambaran tentang urutan-urutan tata cara berwudhu anak tersebut belum mampu melaksanakan secara benar nanti setelah dijelaskan baru anak tersebut mengerti urutan-urutannya itupun harus dilakukan secara berulang-ulang baru bisa melaksanakan secara benar, dalam menjawab tugas guru dapat dilakukan dengan baik sebagai anak berkebutuhan khusus meskipun tidak terlalu detail tetapi sudah mampu memberikan penjelasan sesuai dengan pertanyaan yang diberikan oleh guru.

Dari pengamatan tersebut, pada anak berkebutuhan khusus tuna rungu dalam mempraktekkan cara berwudhu terlihat bahwa ada peningkatan penguasaan materi pembelajaran setelah guru (Ibu Suarni dan Ibu Normayanti) menjelaskan materi pembelajaran dengan menggunakan metode ceramah dan metode demonstrasi yang didukung dengan metode oral, metode membaca ujaran (speech reading), metode isyarat dan komunikasi total. Begitu juga pada aspek perilaku pembelajaran ada perubahan motivasi atau tertarik ikut pembelajaran meskipun pada saat-saat tertentu muncul sedikit kebosanan dan kurang perhatian. Pada anak tuna grahita dalam mempraktikkan tata cara berwudhu terlihat bahwa ada peningkatan penguasaan materi pembelajaran setelah guru (Bapak Muh. Sabri dan Ibu Normayanti) menjelaskan materi pembelajaran dengan menggunakan metode ceramah dan metode demonstrasi yang didukung dengan metode yang diindividualisasikan. Begitu juga pada aspek perilaku pembelajaran ada perubahan motivasi atau tertarik ikut pembelajaran meskipun pada saatsaat tertentu muncul sedikit kebosanan dan kurang perhatian.

Pada pengamatan untuk tata cara shalat pada anak tu terlihat bahwa ada perubahan penguasan materi pembelajaran pada anak didik setelah guru
(Ibu Suarni dan Ibu Normayanti) memberikan penjelasan materi pelajaran dengan menggunakan metode ceramah dan metode demonstrasi yang didukung dengan metode oral, netode membaca ujaran (speech reading), metode isyarat dan komunikasi total, dan juga ada motivasi yang baik dan ketertarikan mengikuti pembelajaran. Hal ini terlihat dari perubahan prilaku pembelajaran yang meningkat.

Sedangkan pada anak tuna grahita dalam mempraktikkan tata cara shalat terlihat bahwa ada perubahan penguasan materi pembelajaran pada anak didik setelah guru (Bapak Muh. Sabri dan Ibu Normayanti) memberikan penjelasan materi pelajaran dengan menggunakan metode ceramah dan metode demonstrasi yang didukung dengan metode yang diindividualisasikan, meskipun ada muncul kebosanan atau kurang perhatian terhadap pelajaran tetapi tetap ada motivasi dan ketertatikan megikuti materi pelajaran, ini dilihat dari perubahan perilaku pembelajaran

\section{Faktor Pendukung dan Penghambat}

Faktor pendukung pelaksanaan pendidikan pada SLB Negeri Parepare antara lain sarana dan prasarana sekolah yang layak dan kondusif untuk mendukung proses pembelajaran karena selain ruang kelas juga terdapat gedung asrama, rumah dinas, perpustakaan. Dari segi lokasi sekolah, meskipun letak sekolah yang jauh dari keramaian tetapi mampu dijangkau dengan transportasi umum akan memudahkan anak yang berkelainan fisik dapat dengan mudah menuju sekolah tanpa kendala.

Tersedianya tenaga pendidik sesuai dengan kompetensinya juga menjadi faktor pendukung dalam proses belajar mengajar, kecuali guru agama yang masih berstatus guru honorer atau guru kontrak. Adanya perhatian terhadap pelajaran ekstrakurikuler yang merangsang siswa atau memotivasi untuk berprestasi sesuai keterampilan yang dimiliki juga menjadi salah satu faktor pendukung, seperti baris berbaris yang banyak mendapatkan penghargaan dari lomba-lomba yang diselenggarakan, melukis dan menggambar yang prestasi pada tingkat nasional, tata rias pengantin, dan dekorasi.

Dalam proses pembelajaran, murid banyak diberikan kesempatan dan kebebasan untuk menyampaikan gagasan sesuai dengan 
kemampuannya sehingga dapat membangkitkan motivasi murid untuk belajar dan meningkatkan kreativitasnya. Guru selalu dan berusaha menciptakan suasana yang kondusif dan menyenangkan dalam proses belajar, dan selalu memotivasi murid sehingga murid memiliki kepercayaan yang tinggi dalam berinteraksi baik di sekolah maupun di lingkungan sosialnya.

Untuk faktor penghambat antara lain, belum adanya guru bidang studi agama yang diangkat langsungoleh Dinas Pendidikan untukmengajar atau ditempatkan di sekolah luar baisa, dan juga belum ada guru bidang studi agama yang berlatarbelakang pendidikan PLB sehingga guru agama yang ada dalam menyampaikan materi pelajaran terkadang masih didampingi guru kelas. Selain itu, buku-buku mata pelajaran khusus Sekoalah Luar Biasa belum mencukupi atau masih kurang sehingga guru masih ada menggunakan buku sekolah umum meskipun bobotnya dikurangi. Media pembelajaran yang masih kurang, seperti media audio atau hearing aids, $\mathrm{Al}$ quran digital, komputer, VCD, model tiruan, alat bina diri, alat musik kesenian, dan alatalat pramuka.

\section{Evaluasi}

Evaluasi pada SLB Negeri Parepare dilakukan untuk mengetahui efektivitas proses pembelajaran dan metode pembelajaran yang dilaksanakan, serta untuk memonitor perkembangan anak baik dalam pengetahuan, keterampilan maupun sikap. Menurut Ibu Suarni, evaluasi yang dilakukan terhadap murid biasanya dilakukan pada saat pembelajaran berlangsung, ini dimaksudkan untuk mengetahui apakah pelajaran yang diberikan dapat dimengerti langsung oleh murid dan untuk mengetahui apakah seorang murid telah memiliki kecakapan-kecakapan atau keterampilan maupun bakat. Misalnya tatacara berwudhu, sebelum pembelajaran dimulai murid sudah ditanya terlebih dahulu bahwa apakah sudah ada yang mengetahui tentang tata cara berwudhu tersebut. Evaluasi seperti ini dapat juga dikatakan sebagai pre-test.

Diakhir semester juga diadakan evaluasi berupa ujian akhir sama seperti sekolah umum lainnya, menurut Ibu suarni, matari ujian bobotnya tidak sama dengan materi ujian sekolah umumnya lainnya, ini dilakukan karena proses yang diharapkan dari anak berkebutuhan khusus adalah lebih kepada aspek psikomotoriknya dan untuk meningkatkan kepercayaan dirinya serta diusahakan dapat lebih mandiri dalam bersosialisasi, olehnya biasanya nilai ujian yang diberikan juga agak tinggi karena dengan mendapatkan nilai yang tinggi anak didik akan merasa termotivasi dan percaya diri ketika nilai ujian tersebut disampaikan kepada teman dan anggota keluarga.

Progress evaluasi juga dilaksanakan oleh guru sendiri ketika pertengahan semester atau program pembelajaran tengah berlangsung, ini dimaksudkan untuk tingkat perubahan murid dalam menerima pelajaran, misalnya apakah metode ceramah tidak membosankan bila dilakukan secara terus menerus, atau perlu metode lain agar murid dapat bersemangat menerima pelajaran. Test tertulis diberikan secara bersamaan dalam satu kelas tetapi untuk anak tuna grahita dibedakan materi ujiannya pada masing-masing anak, anak tuna grahita mempunyai IQ yang berbeda-beda. Begitupun juga dengan test lisan anak tuna rungu tidak pada aspek yang berhubungan dengan audio hanya pada aspek isyarat dan gerak bibir misanya bagaimana menyebutkan tata cara berwudhu, atau ada berapa rukun Islam dan rukun Imam.

\section{PENUTUP}

Perubahan prilaku anak didik dalam mencapai tujuan belajar sudah menyentuh ranah afektif anak didik yaitu pembelajaran yang menyentuh emosional anak didik seperti perasaan, minat, sikap, dan kepatuhan terhadap moralnya, jadi tidak hanya pada ranah kognitif (yang berkaitan dengan aspekaspek berpikir, rasa ingin tahu dan bagaimana memecahkan masalah) dan aspek psikomotorik (yang berhubungan dengan keterampilan yang melibatkan fungsi otot dan syaraf serta psikis) yang selama ini banyak digali.

Tenaga pendidik atau guru mata pelajaran agama pada SLB Negeri Parepare belum berstatus sebagai pegawai tetap dan tidak berlatar pendidikan luar biasa sehingga masih terkadang didampingi oleh guru kelas ketika memberikan materi pelajaran atau pada saat evaluasi dilaksanakan. Metode pembelajaran yang diberikan masih terkesan sedikit monoton karenanya kurangnya dukungan media pembelajaran. Aspek keterampilan yang diberikan bobotnya lebih besar dibanding dengan aspek pengetahuan. Buku-buku pelajaran khusus untuk anak berkebutuhan khusus masih kurang sehingga masih banyak menggunakan buku pelajaran umum. 


\section{UCAPAN TERIMA KASIH}

Ucapan terima kasih kami sampaikan kepada pengelolah Jurnal Al-Qalam atas diterbitkannya artikel ini. Juga ucapan terimakasih dan penghargaan yang setinggi-tingginya kepada informan yang telah meluangkan waktu untuk menemani penulis dalam mengumpulkan data yaitu Ibu $\mathrm{Hj}$. Naslah, S.Pd (Kepala Sekolah SLB Negeri Parepare) dan Ibu Suarni, S.Pd (Guru kelas Tuna Rungu), juga kepada pimpinan pemerintah setempat dalam hal ini Bapak Kepala Kementerian Agama Kota Parepare yang telah memfasilitasi penulis melakukan penelitian di Kota Parera dan tak lupa kepada rekan-rekan penulis yang telah memberikan sumbangsi saran dan kritik dalam penyempurnaan artikel ini.

\section{DAFTAR PUSTAKA}

Ambarjaya, Beni S. 2012. Psikologi Pendidikan dan Pengajaran; Teori dan Praktek. Yogyakarta: CAPS.

Gunawan, Heri. 2012. Kurikulum dan Pembelajaran Agama Islam. Bandung: Alfabeta.

Hamzah B, Uno. 2008. Model Pembelajaran, Menciptakan Proses Belajar Mengajar Yang Kreatif dan Efektif.C.II. Jakarta: Bumi Aksara.

Kustawan, Dedy. 2012. Pedoman Penetapan KKM :
Khusus. Jakarta: Luxima Metro Media.

Makmun, Abin Syamsuddin. 2007. Psikologi Pendidikan; Perangkat Sistem Pengajaran Modul. Bandung: Remaja Rosdakarya.

Peraturan Pemerintah Republik Indonesia Nomor 55 Tahun 2007 Pendidikan dan Pendidikan Keagamaan.

Standar Kompetensi Isi dan Kompetensi Isi Dasar. Sekolah Dasar Luar Biasa tuna grahita sedang (SDLB C1). Direktorat Jenderal Manajemen Pendidikan Dasar dan Menengah. Direktorat Pembinaan Sekolah Luar Biasa. Departemen Pendidikan Nasional 2006.

Syatra, Nuni Yusvavera. 2013. Desain Relasi Efektif Guru dan Murid. Yogyakarta: Buku Biru.

Tohirin. 2005. Psikologi Pembelajaran Pendidikan; Barbasis Integrasi dan Kompetensi. Jakarta: Rajagrafindo Persada.

Triani, Nani. 2012. Panduan Asesmen anak berkebutuhan khusus. Jakarta: Luxima Metro Media.

Undang-Undang Republik Indonesia Nomor 20 Tahun 2003 Tentang Sistem Pendidikan Nasional.

Wardani, I.G.A.K. dkk. 2009. Materi Pokok Pengantar pendidikan Luar Biasa. Jakarta: Universitas Terbuka. 